\title{
Comparison of methods for classification of the coefficient of variation in papaya ${ }^{1}$
}

\author{
Jeferson Pereira Ferreira ${ }^{2}$, Edilson Romais Schmildt ${ }^{3 *}$, Omar Schmildt ${ }^{4}$, Laercio Francisco Cattaneo ${ }^{5}$, \\ Rodrigo Sobreira Alexandre ${ }^{6}$, Cosme Damião Cruz ${ }^{7}$
}

10.1590/0034-737X201663020004

\begin{abstract}
The objective of this work was to study the distribution of values of the coefficient of variation (CV) in the experiments of papaya crop (Carica papaya L.) by proposing ranges to guide researchers in their evaluation for different characters in the field. The data used in this study were obtained by bibliographical review in Brazilian journals, dissertations and thesis. This study considered the following characters: diameter of the stalk, insertion height of the first fruit, plant height, number of fruits per plant, fruit biomass, fruit length, equatorial diameter of the fruit, pulp thickness, fruit firmness, soluble solids and internal cavity diameter, from which, value ranges were obtained for the CV values for each character, based on the methodology proposed by Garcia, Costa and by the standard classification of Pimentel-Gomes. The results obtained in this study indicated that ranges of $\mathrm{CV}$ values were different among various characters, presenting a large variation, which justifies the necessity of using specific evaluation range for each character. In addition, the use of classification ranges obtained from methodology of Costa is recommended.
\end{abstract}

Key words: Carica papaya L., experiment, experimental precision.

\section{RESUMO}

\section{Comparação de metodologias para classificação do coeficiente de variação em mamoeiro}

Objetivou-se com esta pesquisa avaliar a distribuição dos valores de coeficiente de variação (CV) de experimentos com a cultura do mamoeiro (Carica papaya L.), propondo faixas que orientem os pesquisadores na avaliação de seus estudos para diferentes caracteres a campo. Os dados utilizados foram obtidos por revisão bibliográfica em periódicos, dissertações e teses nacionais. Foram considerados os caracteres diâmetro do caule, altura de inserção do primeiro fruto, altura da planta, número de frutos por planta, biomassa de frutos, comprimento de fruto, diâmetro equatorial de fruto, espessura de polpa, firmeza de fruto, sólidos solúveis e diâmetro da cavidade interna, dos quais foram obtidas faixas de valores de $\mathrm{CV}$ para cada caractere com base nas metodologias propostas por Garcia, por Costa, e na classificação padrão de Pimentel-Gomes. Os resultados obtidos indicaram que faixas de valores de CV diferiram entre as diversos caracteres apresentando ampla variação, justificando a necessidade de utilizar faixa de avaliação específica para cada caractere e, que se recomenda o uso das faixas de classificação obtidas a partir da metodologia de Costa.

Palavras-chaves: Carica papaya L., experimentação, precisão experimental.

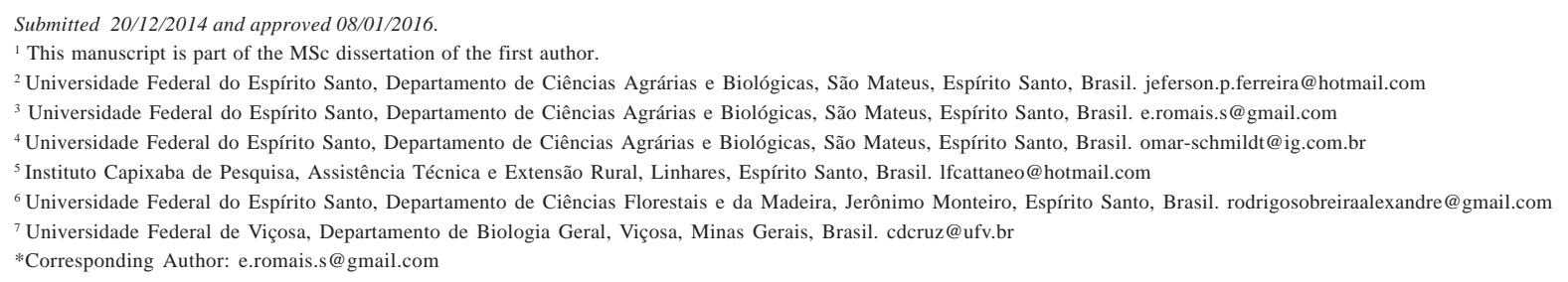




\section{INTRODUCTION}

Papaya (Carica papaya L.) is a tropical fruit of great importance in Brazil. According to data of FAO, in 2013, Brazil was the second largest producer of papaya, with a participation of $12.5 \%$ in the market, behind India, only, which had 44.65\% (FAO, 2015). In Brazil, in 2014, the papaya was grown in an area of 32,118 hectares, where cultivation was predominantly in the states of Bahia (794,565 tons), Espírito Santo (399,790 tons), Ceará (98,773 tons), Minas Gerais (90,052 tons) and Rio Grande do Norte $(69,956$ tons $)$, representing $90.63 \%$ of the total Brazilian production.

Commercial production of papaya has gained importance in Brazil since the 1980s (FAO, 2015) and from then on, the field trial also became more intensive in order to evaluate the demands of research in soil fertility (Oliveira \& Caldas, 2004), breeding (Oliveira et al., 2010), among others.

The coefficient of variation (CV) is a statistic often used as a measure of evaluation of experimental quality. It comprises an estimate of the experimental error in relation to the overall mean, considering that the lower the estimate of the $\mathrm{CV}$, the greater the accuracy of the experiment and vice versa, and, the higher the experimental (higher quality), the lower differences among mean estimates will be significant (Cargnelutti Filho \& Storck, 2007).

Low accurate experiments may lead to incorrect conclusions from the results, increasing the probability of occurrence of Type II error, that is, pointing equality between treatments when actually there is a difference (Judice et al., 2002). The type I error is not affected by the accuracy of the experiment since its occurrence can be controlled by the researcher at the time of statistical test application when the significance level is achieved (Oliveira et al., 2009).

In the area of agriculture experimentation, $\mathrm{CV}$ values of the experiments vary according to the nature of the trial, to the evaluated crops, and especially, to the character under study (Cruz et al., 2012, Fritsche Neto et al., 2012, Couto et al., 2013), being necessary to establish specific classifications for the reality inherent to each crop. Despite all the concern with the quality of studies, researchers on Agricultural Sciences have compared the results of CV of their experiments with those suggested by Pimentel-Gomes (2009), who classifies the coefficients of variation as follows: low when less than 10\%; average, between 10 and 20\%; high, when they are between 20 and 30\%; and very high, when higher than $30 \%$. The issue found with this type of classification is the fact that the characteristics of the evaluated crop and the character studied are not taken into consideration.

To set limits on the distribution of $\mathrm{CV}$ values, Garcia (1989), when working with 146 projects that encompassed species of the genus Pinus and Eucalyptus, proposed to use the relationship between the mean and standard deviation of the $\mathrm{CV}$ values of several experiments, involving characters of the diameter at breast height (DBH), total height, cylindrical volume, survival and percentage of failures. This method has been used to determine CV ranges in corn (Scapim et al, 1995; Fritsche et al, 2012), citrus (Amaral et al., 1997), swine (Judice et al., 1999), legume forage (Clemente \& Muniz, 2000), rice (Costa et al., 2002), cattle (Judice et al., 2002), forage grasses (Clemente \& Muniz, 2002), mate herb (Storck et al., 2002) banana trees (Ledo et al, 2003), soybean (Carvalho et al., 2003), melon (Lima et al., 2004), beans (Oliveira et al., 2009), popcorn (Arnhold \& Milani, 2011), pepper (Silva et al., 2011), sugar cane (Couto et al., 2013). Despite being widely used, the method of Garcia (1989) requires the data to have normal distribution, which does not always occur, making it impossible to study the $\mathrm{CV}$ in data distributions different from the normal.

When working with rice crop data, Costa et al. (2002), suggested an alternative method of CV classification that can be applied regardless of the probability distribution of the CV values, based on the use of the median (Md) and pseudo-sigma (PS), which are measures that according to the authors are more resistant than the mean and standard deviation. This methodology has been already used for determining ranges in coefficient of variation in soybeans (Carvalho et al., 2003), beans (Oliveira et al., 2009), tissue culture (Werner et al., 2012) and sugar cane (Couto et al.; 2013).

Therefore, the objective of this work was to set ranges of coefficient of variation for characters of papaya crop by the methods of Garcia (1989) and Costa et al. (2002), in comparison with the general proposal of Pimentel-Gomes (2009).

\section{MATERIAL AND METHODS}

The data used in this study were obtained by means of a bibliographic review in scientific journals, masters' dissertation and doctoral thesis that contained experiments with papaya. The journals researched were as follows: Acta Scientiarum-Agronomy (2008-2013); Bragantia (1941-2013); Crop Breeding and Applied Biotechnology (2008-2013); Ciência Rural (1995-2013); Enciclopédia Biosfera (2008-2012); Food Science and Technology (1997-2013); Magistra (1983-2000); Pesquisa Agropecuária Brasileira (1999-2013); Pesquisa Agropecuária Tropical (2011-2013); Revista Ciência Agronômica (2010-2013); Revista Brasileira de Fruticultura (2001-2013); Revista Brasileira de Ciências Agrárias (20062013); Revista Caatinga (1976-2013); Revista Ceres (20102013). This study analyzed $287 \mathrm{CV}$ values distributed in 
11 different characters: stem diameter (SD), insertion height of the first fruit (IHFF), plant height (PH), number of fruits per plant (NFP), biomass of the fruit (BMF), fruit length (FL), equatorial diameter of the fruit (EDF), pulp thickness (PT), inner firmness of the fruit (IFF), soluble solids (SS) and diameter of the inner cavity (DIC). This study highlighted that the dissertations and theses used in this work were only those that did not have their articles published, avoiding data duplication and that all reported studies were conducted in Brazil, as recommended by Fritsche Neto et al. (2012).

The classification ranges of $\mathrm{CV}$ for each of the characters were elaborated based on the methodology proposed by Garcia (1989), Costa et al. (2002), and on the standard classification of Pimentel-Gomes (2009).

Table 1: Classification ranges of coefficient of variation (CV) according to the proposal of Garcia (1989), based in mean (average $\mathrm{CV}$ ) and standard deviation (s) of CVs

\begin{tabular}{ll}
\hline Classification & \multicolumn{1}{c}{ Interval } \\
\hline Low & $\mathrm{CV} \leq($ average $\mathrm{CV}-1 \mathrm{~s})$ \\
Mean & (average $\mathrm{CV}-1 \mathrm{~s})<\mathrm{CV} \leq($ average $\mathrm{CV}+1 \mathrm{~s})$ \\
High & $($ average $\mathrm{CV}+1 \mathrm{~s})<\mathrm{CV} \leq($ average $\mathrm{CV}+2 \mathrm{~s})$ \\
Very high & $\mathrm{CV}>($ average $\mathrm{CV}+2 \mathrm{~s})$ \\
\hline
\end{tabular}

Table 2: Classification ranges of coefficient of variation (CV) according to the proposal of Costa et al. (2002), based on the median (Md) and pseudo-sigma (PS)

\begin{tabular}{ll}
\hline Classification & \multicolumn{1}{c}{ Interval } \\
\hline Low & $\mathrm{CV} \leq(\mathrm{Md}-1 \mathrm{PS})$ \\
Average & $(\mathrm{Md}-1 \mathrm{PS})<\mathrm{CV} \leq(\mathrm{Md}+1 \mathrm{PS})$ \\
High & $(\mathrm{Md}+1 \mathrm{PS})<\mathrm{CV} \leq(\mathrm{Md}+2 \mathrm{PS})$ \\
Very high & $\mathrm{CV}>(\mathrm{Md}+2 \mathrm{PS})$ \\
\hline
\end{tabular}

For the methodology of Garcia (1989), the ranges are defined by using the mean of the CVs (average CV) and standard deviations of CVs (s) as follows in Table 1.

For the method proposed by Costa et al. (2002), the ranges of the CVs are classified using the median (Md) and the pseudo-sigma (PS) as shown in Table 2.

The median of the coefficients of variation for the first and third quartile is calculated by the equation $\mathrm{Md}=(\mathrm{Q} 1+$ Q3)/2, which delimits $25 \%$ of end of the distribution.

The pseudo-sigma, expressed by $\mathrm{PS}=\mathrm{IQR} / 1.35$, corresponds to the standard deviation that a normal distribution would need to produce the same interquartile range (IQR = Q3 - Q1). This interpretation of the pseudosigma is justified by the presence of the value of 1.35 , obtained from the normal distribution and corresponds to the distance between Q1 and Q3, which corresponds to $50 \%$ of the data, leaving $25 \%$ in each end. When IQR is divided by 1.35 , the result obtained produces the standard deviation that would be expected to have a normal distribution (Hoaglin et al., 1983; Blanxart et al., 1992).

The CV values were submitted to the test of normality proposed by Lilliefors (Zar, 2010), at $5 \%$ of probability for fulfillment of the requirement of normal distribution of $\mathrm{CV}$ by the method proposed by Garcia (1989). Statistical procedures were performed with the aid of the program Genes (Cruz, 2013) and Office Excel (Levine et al., 2012).

\section{RESULTS AND DISCUSSION}

Descriptive statistics and the normality test of Lilliefors of the 11 characters are shown in Table 3. It can be seen that the characters number of fruits per plant, biomass of the fruits and fruit firmness showed the largest variability, characterized by higher values of standard deviation and that number of fruits per plant and plant height did not

Table 3: Number, mean, median, pseudo-sigma (PS), standard deviation, Lilliefors' normality test, related to the coefficient of variation obtained in experiments with papaya

\begin{tabular}{lcccccc}
\hline Characters $^{(\mathbf{1})}$ & Number & Mean & Median & PS & Standard deviation & Lilliefors $^{(2)}$ \\
\hline SD & 40 & 12.06 & 12.43 & 4.91 & 4.30 & $\mathrm{~S}$ \\
IHFF & 17 & 14.35 & 14.25 & 5.27 & 4.93 & $\mathrm{~S}$ \\
PH & 33 & 10.59 & 9.12 & 3.61 & 4.86 & $\mathrm{~N}$ \\
NFP & 45 & 22.16 & 17.54 & 7.14 & 14.12 & $\mathrm{~N}$ \\
BMF & 37 & 20.76 & 19.35 & 9.25 & 12.37 & $\mathrm{~S}$ \\
FL & 24 & 11.62 & 12.59 & 4.67 & 5.15 & $\mathrm{~S}$ \\
EDF & 20 & 10.27 & 9.90 & 3.00 & 4.00 & $\mathrm{~S}$ \\
PT & 13 & 9.97 & 16.62 & 7.05 & 4.08 & $\mathrm{~S}$ \\
IFF & 22 & 18.29 & 9.47 & 12.31 & 11.50 & $\mathrm{~S}$ \\
SS & 27 & 9.49 & 16.53 & 12.01 & 4.16 & $\mathrm{~S}$ \\
DIC & 9 & 15.67 & & 6.40 & $\mathrm{~S}$ \\
\hline
\end{tabular}

${ }^{(1)}$ Stem diameter (SD); insertion height of the first fruit (IHFF); plant height (PH); number of fruits per plant (NFP); biomass of the fruits (BMF); fruit length (FL), equatorial diameter of the fruit (EDF); pulp thickness (PT); inner firmness of the fruit (IFF), soluble solids (SS) and diameter of the inner cavity (DIC).

${ }^{(2)} \mathrm{S}=$ Normal distribution; $\mathrm{N}=$ not-normal distribution.

Rev. Ceres, Viçosa, v. 63, n.2, p. 138-144, mar/abr, 2016 
have normal distribution. It should be noted that the CV values were determined based on field work where the treatments were of different natures such as: types and rates of fertilizer (Oliveira \& Caldas, 2004); environment of protection (Martelleto et al., 2008); assessments applied to genetic improvement (Oliveira et al., 2010; Dias et al., 2011; Quintal et al., 2011; Vivas et al., 2012). This larger dispersion of data usually occurs due to the strong environmental action on the productive characters in field conditions.

By analyzing the methodologies proposed by Garcia (1989) and Costa et al. (2002), it can be seen that each character presented specific values for ranges of $\mathrm{CV}$, and most of the time they were different from those established by Pimentel-Gomes (2009) (Table 4), justifying the need to consider their nature for classifying those coefficients. Similar results were observed in the determination of the ranges of coefficients of variation for characters of agricultural crops (Oliveira et al., 2009, Cruz et al., 2012, Couto et al., 2013), in animal experiments (Mohallem et al., 2008 ) and plant tissue culture (Werner et al., 2012).

It was found that, in general, for each character, there is greater concordance between the values of the ranges

Table 4: Range of coefficient of variation according to the criteria of classification of Garcia (1989), Costa et al. (2002) and PimentelGomes (2009), for characters of papaya

\begin{tabular}{|c|c|c|c|c|c|c|c|c|c|}
\hline \multirow{2}{*}{ Characters $^{(1)}$} & \multirow{2}{*}{ Methods } & \multirow[b]{2}{*}{ Low } & \multicolumn{6}{|c|}{ Interval (\%) } & \multirow[b]{2}{*}{ Very high } \\
\hline & & & & Average & & & High & & \\
\hline \multirow{3}{*}{ SD } & Garcia (1989) & $\leq 7.77$ & 7.77 & $<\mathrm{CV} \leq$ & 16.36 & 16.36 & $<\mathrm{CV} \leq$ & 20.65 & $>20.65$ \\
\hline & Costa et al. (2002) & $\leq 7.52$ & 7.52 & $<\mathrm{CV} \leq$ & 17.34 & 17.34 & $<\mathrm{CV} \leq$ & 22.25 & $>22.25$ \\
\hline & Pimentel-Gomes (2009) & $\leq 10.00$ & 10.00 & $<\mathrm{CV} \leq$ & 20.00 & 20.00 & $<\mathrm{CV} \leq$ & 30.00 & $>30.00$ \\
\hline \multirow{3}{*}{ IHFF } & Garcia (1989) & $\leq 9.42$ & 9.42 & $<\mathrm{CV} \leq$ & 19.28 & 19.28 & $<\mathrm{CV} \leq$ & 24.22 & $>24.22$ \\
\hline & Costa et al. (2002) & $\leq 8.98$ & 8.98 & $<\mathrm{CV} \leq$ & 19.52 & 19.52 & $<\mathrm{CV} \leq$ & 24.80 & $>24.80$ \\
\hline & Pimentel-Gomes (2009) & $\leq 10.00$ & 10.00 & $<\mathrm{CV} \leq$ & 20.00 & 20.00 & $<\mathrm{CV} \leq$ & 30.00 & $>30.00$ \\
\hline \multirow{3}{*}{$\mathrm{PH}$} & Garcia (1989) & - & - & - & - & - & - & - & - \\
\hline & Costa et al. (2002) & $\leq 8.98$ & 8.98 & $<\mathrm{CV} \leq$ & 12.72 & 12.72 & $<\mathrm{CV} \leq$ & 16.33 & $>16.33$ \\
\hline & Pimentel-Gomes (2009) & $\leq 10.00$ & 10.00 & $<\mathrm{CV} \leq$ & 20.00 & 20.00 & $<\mathrm{CV} \leq$ & 30.00 & $>30.00$ \\
\hline \multirow{3}{*}{ NFP } & Garcia (1989) & - & - & - & - & - & - & - & - \\
\hline & Costa et al. (2002) & $\leq 10.40$ & 10.40 & $<\mathrm{CV} \leq$ & 24.68 & 24.68 & $<\mathrm{CV} \leq$ & 31.82 & $>31.82$ \\
\hline & Pimentel-Gomes (2009) & $\leq 10.00$ & 10.00 & $<\mathrm{CV} \leq$ & 20.00 & 20.00 & $<\mathrm{CV} \leq$ & 30.00 & $>30.00$ \\
\hline \multirow{3}{*}{$\mathrm{BMF}$} & Garcia (1989) & $\leq 8.39$ & 8.39 & $<\mathrm{CV} \leq$ & 33.12 & 33.12 & $<\mathrm{CV} \leq$ & 45.49 & $>45.49$ \\
\hline & Costa et al. (2002) & $\leq 10.09$ & 10.09 & $<\mathrm{CV} \leq$ & 28.60 & 28.60 & $<\mathrm{CV} \leq$ & 37.85 & $>37.85$ \\
\hline & Pimentel-Gomes (2009) & $\leq 10.00$ & 10.00 & $<\mathrm{CV} \leq$ & 20.00 & 20.00 & $<\mathrm{CV} \leq$ & 30.00 & $>30.00$ \\
\hline \multirow{3}{*}{ FL } & Garcia (1989) & $\leq 6.47$ & 6.47 & $<\mathrm{CV} \leq$ & 16.77 & 16.77 & $<\mathrm{CV} \leq$ & 21.91 & $>21.91$ \\
\hline & Costa et al. (2002) & $\leq 7.92$ & 7.92 & $<\mathrm{CV} \leq$ & 17.26 & 17.26 & $<\mathrm{CV} \leq$ & 21.93 & $>21.93$ \\
\hline & Pimentel-Gomes (2009) & $\leq 10.00$ & 10.00 & $<\mathrm{CV} \leq$ & 20.00 & 20.00 & $<\mathrm{CV} \leq$ & 30.00 & $>30.00$ \\
\hline \multirow{3}{*}{ EDF } & Garcia (1989) & $\leq 6.27$ & 6.27 & $<\mathrm{CV} \leq$ & 14.26 & 14.26 & $<\mathrm{CV} \leq$ & 18,26 & $>18.26$ \\
\hline & Costa et al. (2002) & $\leq 6.90$ & 6.90 & $<\mathrm{CV} \leq$ & 12.89 & 12.89 & $<\mathrm{CV} \leq$ & 15.89 & $>15.89$ \\
\hline & Pimentel-Gomes (2009) & $\leq 10.00$ & 10.00 & $<\mathrm{CV} \leq$ & 20.00 & 20.00 & $<\mathrm{CV} \leq$ & 30.00 & $>30.00$ \\
\hline \multirow{3}{*}{ PT } & Garcia (1989) & $\leq 5.89$ & 5.89 & $<\mathrm{CV} \leq$ & 14.05 & 14.05 & $<\mathrm{CV} \leq$ & 18.13 & $>18.13$ \\
\hline & Costa $(2002)$ & $\leq 5.46$ & 5.46 & $<\mathrm{CV} \leq$ & 13.58 & 13.58 & $<\mathrm{CV} \leq$ & 17.64 & $>17.64$ \\
\hline & Pimentel-Gomes (2009) & $\leq 10.00$ & 10.00 & $<\mathrm{CV} \leq$ & 20.00 & 20.00 & $<\mathrm{CV} \leq$ & 30.00 & $>30.00$ \\
\hline \multirow{3}{*}{ IFF } & Garcia (1989) & $\leq 6.79$ & 6.79 & $<\mathrm{CV} \leq$ & 29.79 & 29.79 & $<\mathrm{CV} \leq$ & 41.28 & $>41.28$ \\
\hline & Costa et al. (2002) & $\leq 6.86$ & 6.86 & $<\mathrm{CV} \leq$ & 26.39 & 26.39 & $<\mathrm{CV} \leq$ & 36.15 & $>36.15$ \\
\hline & Pimentel-Gomes (2009) & $\leq 10.00$ & 10.00 & $<\mathrm{CV} \leq$ & 20.00 & 20.00 & $<\mathrm{CV} \leq$ & 30.00 & $>30.00$ \\
\hline \multirow{3}{*}{ SS } & Garcia (1989) & $\leq 5.33$ & 5.33 & $<\mathrm{CV} \leq$ & 13.65 & 13.65 & $<\mathrm{CV} \leq$ & 17.82 & $>17.82$ \\
\hline & Costa et al. (2002) & $\leq 5.56$ & 5.56 & $<\mathrm{CV} \leq$ & 13.37 & 13.37 & $<\mathrm{CV} \leq$ & 17.27 & $>17.27$ \\
\hline & Pimentel-Gomes (2009) & $\leq 10.00$ & 10.00 & $<\mathrm{CV} \leq$ & 20.00 & 20.00 & $<\mathrm{CV} \leq$ & 30.00 & $>30.00$ \\
\hline \multirow{3}{*}{ DIC } & Garcia (1989) & $\leq 9.27$ & 9.27 & $<\mathrm{CV} \leq$ & 22.07 & 22.07 & $<\mathrm{CV} \leq$ & 28.47 & $>28.47$ \\
\hline & Costa et al. (2002) & $\leq 12.04$ & 12.04 & $<\mathrm{CV} \leq$ & 21.02 & 21.02 & $<\mathrm{CV} \leq$ & 25.51 & $>25.51$ \\
\hline & Pimentel-Gomes (2009) & $\leq 10.00$ & 10.00 & $<\mathrm{CV} \leq$ & 20.00 & 20.00 & $<\mathrm{CV} \leq$ & 30.00 & $>30.00$ \\
\hline
\end{tabular}

${ }^{(1)}$ Stem diameter (SD); insertion height of the first fruit (IHFF); plant height (PH); number of fruits per plant(NFP); biomass of the fruits (BMF); equatorial diameter of the fruit (EDF); pulp thickness (PT); inner firmness of the fruit (IFF), soluble solids (SS) and diameter of the inner cavity (DIC). 
when comparing the methodologies of Garcia (1989) and Costa et al. (2002), and more discrepancy of them with the classification proposed by Pimentel-Gomes (2009). As the method described by Costa et al. (2002) is based on the median and the pseudo-sigma, more robust measures than the mean and standard deviation as described by the authors, it is possible to establish the intervals of classification that do not depend on the distribution of $\mathrm{CV}$ values, which gives credibility to results found in this work. Similar behaviors were found by Carvalho et al. (2003) when they studied the coefficient of variation in soybean and Couto et al. (2013), when studying coefficients of variation in experiments with sugarcane.
Plant height, equatorial diameter of the fruit, soluble solids and pulp thickness are noted for their lower amplitude in the ranges of coefficient of variation (Table 4) and also for presenting lower values of median (Table 3). Similar behavior was observed by Mohallem et al. (2008) in the study of different characters in broilers. For the four characters, the $\mathrm{CVs}$ are classified as very high with values lower than $20 \%$, unlike the standard classification of Pimentel-Gomes (2009), who classifies CVs as very high for values greater than $30 \%$.

Percentage frequency of the number of coefficient of variation evaluated by classification range is presented in Table 5. It is noted that the methodology proposed by

Table 5: Percentage frequency (\%) of the coefficient of variation for characters of the papaya

\begin{tabular}{|c|c|c|c|c|c|}
\hline \multirow{2}{*}{ Characters $^{(1)}$} & \multirow{2}{*}{ Methods } & \multicolumn{4}{|c|}{ Frequencies (\%) } \\
\hline & & Low & Average & High & Very high \\
\hline \multirow{3}{*}{ SD } & Garcia (1989) & 17.50 & 65.00 & 17.50 & 0.00 \\
\hline & Costa et al. (2002) & 17.50 & 70.00 & 12.50 & 0.00 \\
\hline & Pimentel-Gomes (2009) & 27.50 & 65.00 & 7.50 & 0.00 \\
\hline \multirow{3}{*}{ IHFF } & Garcia (1989) & 11.76 & 76.50 & 11.76 & 0.00 \\
\hline & Costa et al. (2002) & 11.76 & 64.47 & 23.52 & 0.00 \\
\hline & Pimentel-Gomes (2009) & 11.76 & 65.30 & 25.60 & 0.00 \\
\hline \multirow{3}{*}{ PH } & Garcia (1989) & - & - & - & - \\
\hline & Costa et al. (2002) & 33.33 & 42.42 & 9.16 & 15.09 \\
\hline & Pimentel-Gomes (2009) & 40.48 & 42.42 & 9.09 & 8.00 \\
\hline \multirow{3}{*}{ NFP } & Garcia (1989) & - & - & - & - \\
\hline & Costa et al. (2002) & 6.65 & 53.33 & 17.77 & 22.23 \\
\hline & Pimentel-Gomes (2009) & 6.63 & 51.11 & 20.00 & 22.20 \\
\hline \multirow{3}{*}{$\mathrm{BMF}$} & Garcia (1989) & 17.51 & 46.92 & 27.16 & 6.71 \\
\hline & Costa et al. (2002) & 18.91 & 48.64 & 27.02 & 8.40 \\
\hline & Pimentel-Gomes (2009) & 18.90 & 35.13 & 21.62 & 24.35 \\
\hline \multirow{3}{*}{ FL } & Garcia (1989) & 20.83 & 66.66 & 8.33 & 4.16 \\
\hline & Costa et al. (2002) & 20.83 & 70.83 & 8.35 & 0.00 \\
\hline & Pimentel-Gomes (2009) & 25.00 & 66.66 & 8.33 & 0.00 \\
\hline \multirow{3}{*}{ EDF } & Garcia (1989) & 18.00 & 60.00 & 14.02 & 5.34 \\
\hline & Costa et al. (2002) & 20.00 & 66.57 & 10.00 & 7.00 \\
\hline & Pimentel-Gomes (2009) & 55.00 & 45.00 & 0.00 & 0.00 \\
\hline \multirow{3}{*}{ PT } & Garcia (1989) & 27.38 & 41.77 & 22.64 & 5.02 \\
\hline & Costa et al. (2002) & 28.84 & 42.76 & 23.38 & 6.74 \\
\hline & Pimentel-Gomes (2009) & 30.76 & 44.28 & 24.96 & 0.00 \\
\hline \multirow{3}{*}{ IFF } & Garcia (1989) & 13.04 & 75.91 & 4.34 & 4.34 \\
\hline & Costa et al. (2002) & 13.63 & 80.00 & 4.54 & 9.09 \\
\hline & Pimentel-Gomes (2009) & 22.72 & 36.36 & 22.72 & 18.18 \\
\hline \multirow{3}{*}{ SS } & Garcia (1989) & 17.64 & 63.52 & 22.22 & 0.00 \\
\hline & Costa et al. (2002) & 18.51 & 66.66 & 22.22 & 0.00 \\
\hline & Pimentel-Gomes (2009) & 44.41 & 29.62 & 25.97 & 0.00 \\
\hline \multirow{3}{*}{ DIC } & Garcia (1989) & 20.64 & 50.38 & 29.02 & 0.00 \\
\hline & Costa et al. (2002) & 22.22 & 55.55 & 21.75 & 0.00 \\
\hline & Pimentel-Gomes (2009) & 20.13 & 66.43 & 22.44 & 0.00 \\
\hline
\end{tabular}

(1) Stem diameter (SD); insertion height of the first fruit (IHFF); plant height (PH); number of fruits per plant(NFP); biomass of the fruits (BMF); equatorial diameter of the fruit (EDF); pulp thickness (PT); inner firmness of the fruit (IFF), soluble solids (SS) and diameter of the inner cavity (DIC).

Rev. Ceres, Viçosa, v. 63, n.2, p. 138-144, mar/abr, 2016 
Costa et al. (2002), when compared with the methodology of Garcia1989) and the proposal made by Pimentel-Gomes (2009), is the one that concentrates a higher percentage of values within the average range of classification of coefficient of classification, for most of the characters evaluated. Thus, the methodology proposed by Costa et al. (2002) may be considered stricter, classifying mostly experiments with high precision, that is, those with low values for CV's.

\section{CONCLUSIONS}

Characters that presented normal distribution of the coefficients of variation present closer classification ranges among the methods presented by Garcia (1989) and Costa et al. (2002) and are more uneven in relation to the standard classification of Pimentel-Gomes (2009).

The number of papaya fruits presented larger limits of range of coefficient of variation.

The equatorial diameter of the fruit presented the lowest limit values of the range of the coefficient of variation.

The ranges of values of the coefficient of variation differ among the different characters, showing wide variation, justifying the need to use specific evaluation range for each character.

It is recommended to use the classification according to Costa et al. (2002) since it is the one that concentrates a higher percentage of values within the average range of classification of coefficient of variation, for most characters.

\section{ACKNOWLEDGEMENTS}

To Fundação de Amparo à Pesquisa e Inovação do Espírito Santo (FAPES) for granting scholarship to the first author.

\section{REFERENCES}

Amaral AM, Muniz JA \& Souza M (1997) Avaliação do coeficiente de variação como medida da precisão na experimentação com citros. Pesquisa Agropecuária Brasileira, 32:1221-1225.

Arnhold E \& Milani KF (2011) Rank-ordering coefficients of variation for popping expansion. Acta Scientiarum. Agronomy, $33: 527-531$.

Blanxart MF, Cosialis LS, Olmos JG, Puig RF \& Oset JT (1992) Análisis exploratório de datos: nuevas técnicas estadísticas. Barcelona, Promociones y Pubicaciones Universitarias. 296p.

Cargnelutti Filho A \& Storck L (2007) Estatísticas de avaliação da precisão experimental em ensaios de cultivares de milho. Pesquisa Agropecuária Brasileira, 42:17-24.

Carvalho CGP, Arias, CAA, Toledo JFF, Almeida LA, Kiihl RAS, Oliveira MF, Hiromoto DM \& Takeda C (2003) Proposta de classificação dos coeficientes de variação em relação à produtividade e altura da planta de soja. Pesquisa Agropecuária Brasileira, 38:187-193.
Clemente AL \& Muniz JA (2002) Avaliação do coeficiente de variação em experimentos com gramíneas forrageiras. Ciência e Agrotecnologia, 26:197-203.

Clemente AL \& Muniz JA (2000) Estimativas de faixas de coeficientes de variação em leguminosas forrageiras para avaliação da precisão experimental. Ciência e Agrotecnologia, 24:738-742.

Costa NHAD, Seraphin JC \& Zimmermann FJP (2002) Novo método de classificação de coeficientes de variação para a cultura do arroz de terras altas. Pesquisa Agropecuária Brasileira, $37: 243-249$.

Couto MF, Peternelli LA \& Barbosa MHP (2013) Classification of the coefficients of variation for sugarcane crops. Ciência Rural, 43:957-961.

Cruz EA, Moreira GR, Paula MO \& Moura Oliveira ACM (2012) Coeficiente de variação como medida de precisão em experimentos com tomate em ambiente protegido. Enciclopédia Biosfera, 8:221-233.

Cruz CD (2013) GENES - a software package for analysis in experimental statistics and quantitative genetics. Acta Scientiarum. Agronomy, 35:271-276.

Dias NLP, Oliveira EO \& Dantas JLL (2011) Avaliação de genótipos de mamoeiro com uso de descritores agronômicos e estimação de parâmetros genéticos. Pesquisa Agropecuária Brasileira, 46:1471-1479.

FAO (2013) Faostat: Agriculture: Production Rome. Disponível em: <http://www.faostat.org >. Acessado em: 24 de dezembro de 2015.

Fritsche Neto R, Vieira RA, Scapim CA, Miranda GV \& Rezende LM (2012) Updating the ranking of the coefficients of variation from maize experiments. Acta Scientiarum. Agronomy, 34:99101.

Garcia CH (1989) Tabelas para classificação do coeficiente de variação. Piracicaba, IPEF. 12p. (Circular técnica, 171).

Hoaglin DC, Mosteller F \& Tukey JW (1983) Understanding robust and exploratory data analysis. New York, John Wiley. 447p.

IBGE (2014) Banco de dados agregados: culturas permanentes Mamão. Disponível em: < http://www.sidra.ibge.gov.br>. Acessado em 24 de dezembro de 2015.

Judice MG, Muniz JA, Aquino LH \& Bearzoti E (2002) Avaliação da precisão experimental em ensaios com bovinos de corte. Ciência e Agrotecnologia, 26:1035-1040.

Judice MG, Muniz JA \& Carvalheiro R (1999) Avaliação do coeficiente de variação em experimentos com suínos. Ciência e Agrotecnologia, 23:170-173.

Ledo CAS, Silva SO \& Conceição KS (2003) Avaliação do coeficiente de variação na experimentação com bananeira. In: Simpósio brasileiro sobre bananicultura, Paracatu. Anais, Campo. p.238-240.

Levine DM, Stephan DF, Krehbiel TC \& Berenson ML (2012) Estatística: teoria e aplicações usando o Microsoft Excel em português. $6^{a}$ ed. Rio de Janeiro, LTC Editora. 832p.

Lima LL, Nunes GHS \& Bezerra Neto F (2004) Coeficientes de variação de algumas características do meloeiro: uma proposta de classificação. Horticultura Brasileira, 22:14-17.

Martelleto LAP, Ribeiro RLD, Martelleto MS, Vasconcellos MS, Marin SLD \& Pereira MB (2008) Cultivo orgânico do mamoeiro 'Baixinho de Santa Amália' em diferentes ambientes de proteção. Revista Brasileira de Fruticultura, 30:662-666.

Mohallem DF, Tavares M, Silva PL, Guimarães EC \& Freitas RF (2008) Avaliação do coeficiente de variação com medida de precisão em experimentos com frangos de corte. Arquivo Brasileiro de Medicina Veterinária e Zootecnia, 60:449-453. 
Oliveira AM G \& Caldas RC (2004) Produção do mamoeiro em função de adubação com nitrogênio, fósforo e potássio. Revista Brasileira de Fruticultura, 26:160-163

Oliveira EJ, Lima DS, Lucena RS, Motta TB \& Dantas JL (2010) Correlações genéticas e análise de trilha para número de frutos comerciais por planta em mamoeiro. Pesquisa Agropecuária Brasileira, 45:855-862

Oliveira RL, Muniz JA, Andrade MJB \& Reis RL (2009) Precisão experimental em ensaios com a cultura do feijão. Ciência e Agrotecnologica, 33:113-119.

PimenteL-Gomes F (2009) Curso de estatística experimental. 15 ed. Piracicaba, FEALQ. 451p.

Quintal SSR, Viana AP, Gonçalves LSA, Pereira MG \& Amaral Junior AT (2012) Divergência genética entre acessos de mamoeiro por meio de variáveis morfoagronômicas. Semina. Ciências Agrárias, 33:131-142.

Scapim CA, Carvalho CGP \& Cruz CD (1995) Uma proposta de classificação dos coeficientes de variação para a cultura do mi1ho. Pesquisa Agropecuária Brasileira, 30:683-686.
Silva AR, Cecon PR, Rêgo ER \& Nascimento M (2011) Avaliação do coeficiente de variação experimental para caracteres de frutos de pimenteiras. Revista Ceres, 58:168-171.

Storck L, Lúcio ADC, Santos PM, Carvalho MP \& CardinaL ABB (2002) Precisão experimental em erva-mate (Ilex paraguariensis St. Hil.). Ciência Florestal, 12:159-161.

Vivas M, Silveira SF \& Pereira MG (2012) Prediction of genetic gain from selection indices for disease resistance in papaya hybrids. Revista Ceres, 59:781-786.

Werner ET, Motta LB, Martins MQ, Lima ABP \& Schmildt ER (2012) Coeficiente de variação como medida da precisão em experimentos de cultura de tecidos de plantas. Plant Cell Culture \& Micropropagation, 8:27-36.

ZAR JH (2010) Biostatistical analysis. 5ª ed. Upper Saddle River, Pearson. 944p. 